\title{
Inverted and horizontal impacted third molars in an Early Modern skull from Wroclaw, Poland: a case report
}

\author{
P. Dąbrowski1 , M. Kulus², A. Cieślik ${ }^{3}$, K. Staszak ${ }^{4}$, T. Staniowski ${ }^{5}$ \\ 'Division of Normal Anatomy, Department of Human Morphology and Embryology, \\ Wroclaw Medical University, Wroclaw, Poland \\ 2Division of Histology and Embryology, Department of Human Morphology and Embryology, \\ Wroclaw Medical University, Wroclaw, Poland \\ ${ }^{3}$ Department of Anthropology, Hirszfeld Institute of Immunology and Experimental Therapy, \\ Polish Academy of Sciences, Wroclaw, Poland \\ ${ }^{4}$ Department of Oral Anatomy, Wroclaw Medical University, Wroclaw, Poland \\ ${ }^{5}$ Department of Conservative Dentistry and Pedodontics, Wroclaw Medical University, Wroclaw, Poland
}

[Received: 12 June 2018; Accepted: 9 July 2018]

Background: An impacted tooth is one of the most commonly occurring dental anomalies, although some types of impaction (i.e. inverted angulation) may be considered rare finding. There are many hypotheses regarding impaction aetiology. One of the most popular hypotheses suggested that this condition may result from insufficient space in retromolar space, other: improper angulation of tooth bud, malposition of the tooth germ or hereditary factors, insufficient interproximal attrition, ectopy or dysfunction of genes necessary for proper tooth eruption. This study aims to present the odontological and paleopathological assessment of the impacted molars observed within the skull excavated from an early modern cemetery in Wroclaw.

Materials and methods: The skull used in the study was complete and in a good state of preservation. It belonged to an adult individual whose body was buried at the former Salvator Cemetery (currently Czysty Square). The individual's dentition was almost completely lost antemortem. Only second molars preserved within the maxillae (bilaterally) and the mandible was almost edentulous as well. The morphometric traits have been taken according to standards established by R. Martin. Macroscopic observations were supported by X-rays and computed tomography imaging.

Results: The age at death was estimated at 20-35 years. Comparison of the metric characteristics of skull with the reference material reveals that it is much smaller than the average female skull from this series. Morphometric indices calculated for both splanchocranium and neurocranium allow defining the skull and jaw as short, which could be an important factor involved in the teeth impaction.

Conclusions: Atypical impaction of the third molars could result from small size of skull and could have significantly deteriorated the quality of life of the individual. (Folia Morphol 2019; 78, 1: 214-220)

Key words: tooth impaction, tooth abnormalities, paleopathology

Address for correspondence: Dr. P. Dąbrowski, Division of Normal Anatomy, Department of Human Morphology and Embryology, Wroclaw Medical University, ul. Chałubińskiego 6a, 50-368 Wrocław, Poland, e-mail: pawel.dabrowski@umed.wroc.pl 


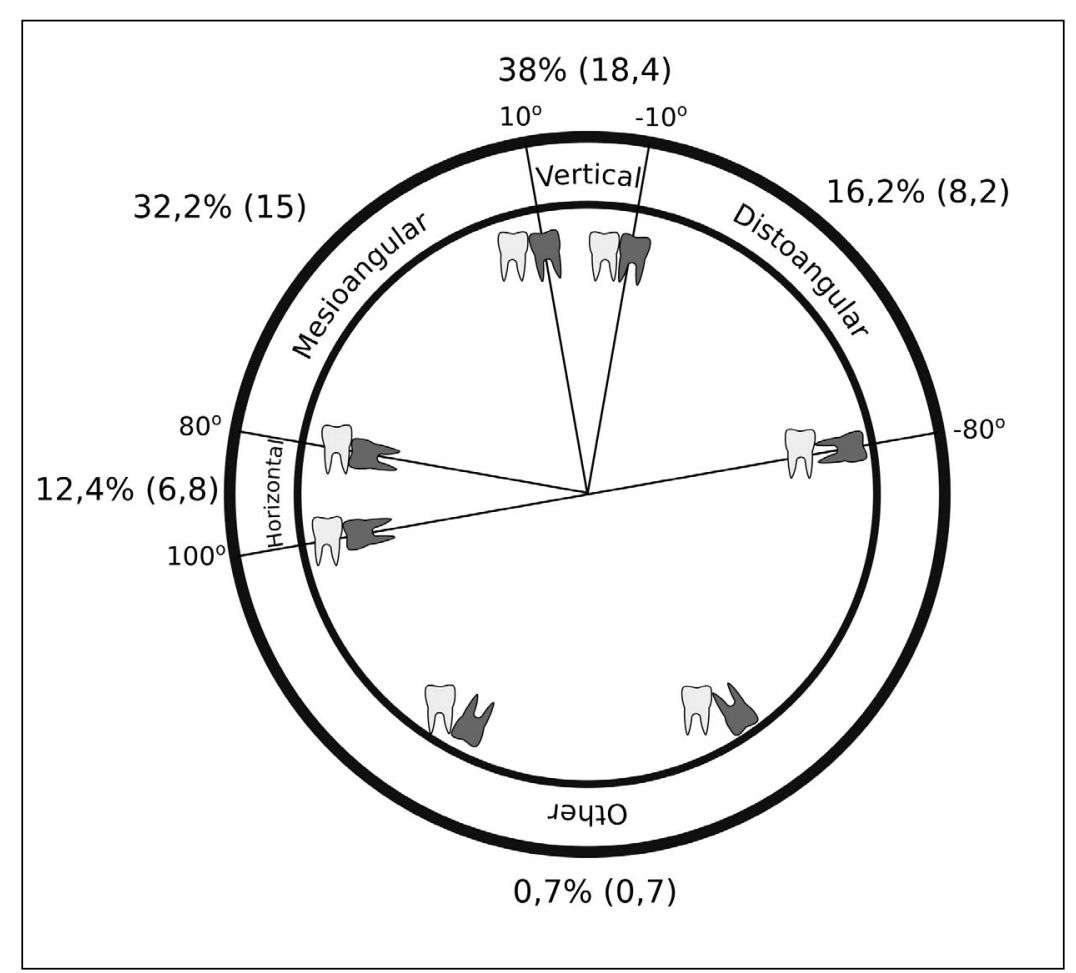

Figure 1. Winters classification of impacted molar angulation. Frequency varies depending on the source and study population (see the text for more details); here we present mean per cent of each type, standard deviation are in round brackets. Sources: $[1,10,22,25,26,28]$.

\section{INTRODUCTION}

An impacted tooth is a fully developed tooth that has failed to erupt and is retained within the bone tissue of the maxilla or mandible [11]. Impacted tooth is one of the most commonly occurring dental anomalies. Frequency varies depending on the source and study population: $4.5 \%$ of dental anomalies in modern population of North Karnataka, India [10], $19.2 \%$ in Jatt, Israel [22], 26.2\% in Konya, Turkey [28], $56.5 \%$ in Bhopal, India [25], 48.3\% in Ordu, Turkey [1], $69 \%$ in Singapore, China [26]. The most commonly impacted teeth are mandibular and maxillary third molars, followed by maxillary canines [6, 22].

Tooth impaction is usually classified with regard to the level of impaction and its position - Pell and Gregory's system for mandibular and Archer's for maxillary teeth - as well as angulation - Winter's classification [17, 35]. Classification of the angulation with mean prevalence of each type is presented in Figure 1. Although frequencies of angulations varies between different study populations, in every publication inverted angulation (classified usually as "other") is the rarest, ranging from $0.1 \%$ to $1.8 \%$ of impacted teeth $[1,2,9,23,25,26,35]$.

There are many hypotheses regarding to impaction aetiology. One of the most popular suggests it may result from insufficient space in retromolar space [11]; however, it is frequently inadequate explanation [12]. Another possible explanation of this phenomenon is the improper angulation of the tooth bud, malposition of the tooth germ or hereditary factors, insufficient interproximal attrition [11] or ectopy [16] which may lead to the wrong path of eruption. Dysfunction of genes necessary for proper tooth eruption, such as CSF-1, OPG, VEGF, RANK, RANKL, BMPs [34] could also result in tooth impaction.

Impacted tooth may be associated with pathological conditions such as: pain, swelling, caries, pericoronitis, bone loss, root resorption of adjacent teeth, suppuration, ulceration at check/tongue, odontogenic cysts and other $[6,35]$. Impacted tooth surgical removal is also burdened with risk of alveolar nerve damaging [11].

The aim of the study was to present the odontological and paleopathological assessment of the impacted molars observed within the skull No. 595 excavated from an early modern cemetery at Czysty Square (pl. Czysty) in Wroclaw. The paper discusses in detail both the biological consequences of the dental anomaly and their impact on the individual's quality of life. 


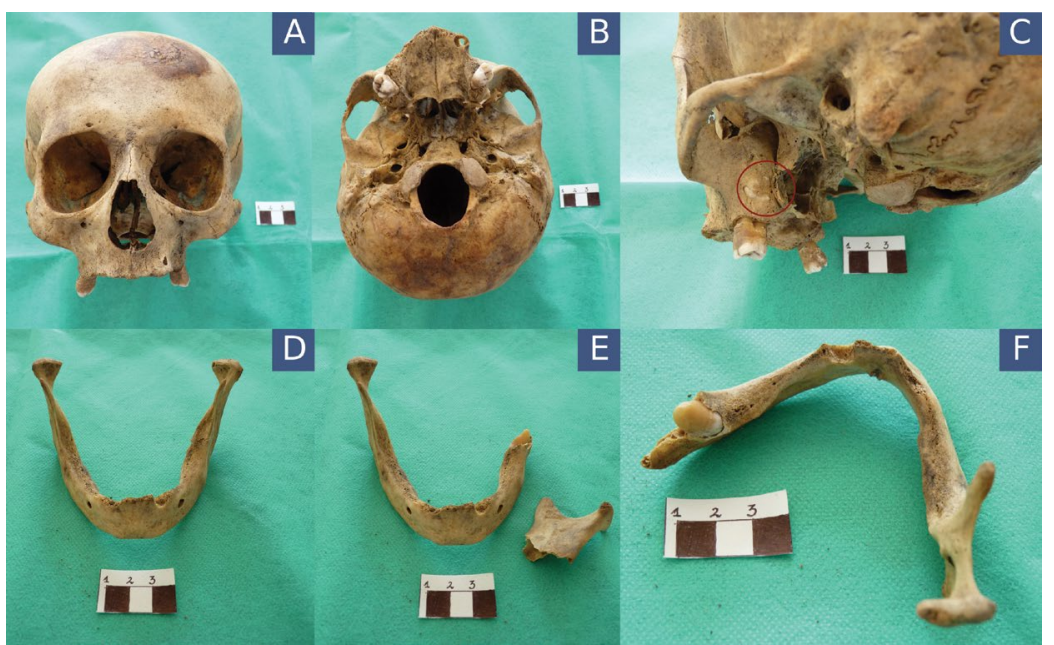

Figure 2. A. Skull No. 595 in anterior plane; B. Inferior view; C. Maxillary impacted molar (in red circle), horizontally inverted; D. Whole mandibula, almost edentulous; E, F. Broken mandibular left ramus, exposing impacted third molar.

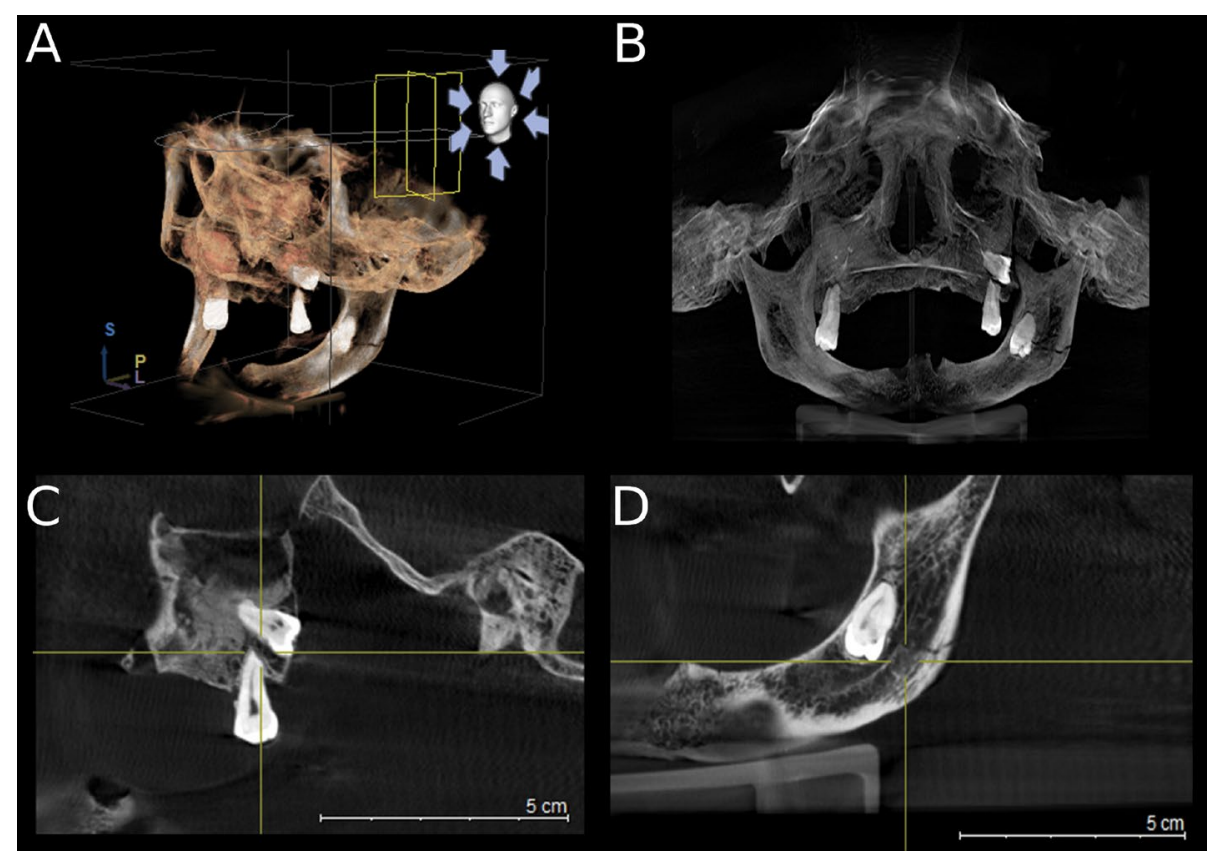

Figure 3. A. Computed tomography image revealing two impacted molars; B. Roentgenography image of anterior plane; C. Impacted maxillary molar, classified as D according to modified Archer's classification; D. Impacted mandibular molar, classified as IIIC in Pell and Gregory's scale.

\section{MATERIALS AND METHODS}

The examined cranium belonged to an adult individual whose skeleton was excavated from grave No. 595, at the former Salvator Cemetery (currently Czysty Square). Historical background of the cemetery, its population and artefacts obtained during excavations were described elsewhere [8, 32]. Shortly: this cemetery was established in 1541, next to Salvator Church, the first protestant parish temple of Wroclaw. The cemetery was localised outside the city walls, near southern gate. It was a burial place for the people coming from the surrounding villages and socially excluded individuals (i.e. suicides and convicts). The cemetery ceased to function in the half of XVIII century. Excavations led in 2006-2007 included 1426 identified burials.

Grave No. 595 contained a partly preserved skeleton: a complete skull in a good state of preservation (cranium, Cr) with almost total loss of dentition of the maxillae (only the second pair of molars preserved on both sides) and the almost edentulous mandible (Figs. 2, 3). The skeletal material from Czysty Square necropolis is currently a part of the osteological col- 
lection of the Department of Anthropology, Hirszfeld Institute of Immunology and Experimental Therapy, Polish Academy of Sciences, Wroclaw, Poland.

Due to lack of most of the postcranial skeleton, sex of the individual was estimated based on the expression of following morphological features of the skull: nuchal crest, mastoid process, supraorbital margin, prominence of glabella, mental eminence [5].

Age at death was estimated based on the cranial sutures closure stage [5] and the preserved molars wear pattern [4].

For morphometric measurements of the skull, we used dedicated standard anthropometric equipment. The measurements (listed in Table 1) have been taken according to the technique established by Martin and Saller [21], which were chosen due to the availability of the comparative data: adult female skulls from Czysty Square in Wroclaw [32] and XVII-XIX century. Warsaw cemeteries [15]. Morphometric parameters were used to calculate indexes described by Martin and Hrdlička-Kočka [20, 21].

To visualise impacted teeth in the bone structures of the alveolar arches we used the X-ray pantomographic technique (Sirona Orthophos XG5DS 60 kV/ $13 \mathrm{~mA}$ apparatus), with exposure time of $14.1 \mathrm{~s}$, and computer tomography scanning with multilevel image analysis without contrast on by Sirona Galileos $3 \mathrm{D} 85 \mathrm{kV}$, with an effective radiation dose of $21 \mathrm{mAs}$. Clinical classifications established by Pell and Gregory or Archer was used to assess the molars retention (for mandibular and maxillary teeth, respectively) and Winter's classification to estimate the position of impacted molar in the maxilla and in core and branch of the mandible [11].

\section{RESULTS}

\section{Age and sex}

Most of the analysed morphological features of sexual dimorphism in skull No. 595 were indicative of the female sex (i.e. weakly pronounced supraorbital margins, zygomatic arches, mastoid processes and external occipital protuberance). The closure stage of the cranial sutures corresponded with a form characteristic of a biological age between 20 and 35 years (young adult). This estimation was supported by molars wear analysis.

\section{Morphometrics}

Comparison of the metric traits between skull No. 595 and reference data revealed that it is much
Table 1. Parameters used in evaluation of skull morphology (according to [21])

\begin{tabular}{lcc}
\hline $\begin{array}{l}\text { Martins } \\
\text { number }\end{array}$ & Abbreviation & Full name \\
\hline M-1 & g-op & glabella-opisthocranion \\
M-8 & eu-eu & eurion-eurion \\
M-9 & ft-ft & frontotemporale-frontotemporale \\
M-10 & co-co & coronale-coronale \\
M-11 & au-au & auriculare-auriculare \\
M-13 & ms-ms & mastoideale-mastoideale \\
M-45 & zy-zy & zygion-zygion \\
M-51 & mf-ek & maxillofrontale-ectoconchion \\
M-52 & orb-heigh & orbital heigh \\
M-54 & apt-apt & apertura piriformis-apertura piriformis \\
M-55 & n-ns & nasion-nasospinale \\
M-62 & ol-sta & orale-staphylion \\
M-63 & enm-enm & endomolare-endomolare \\
M-66 & go-go & gonion-gonion \\
\hline
\end{tabular}

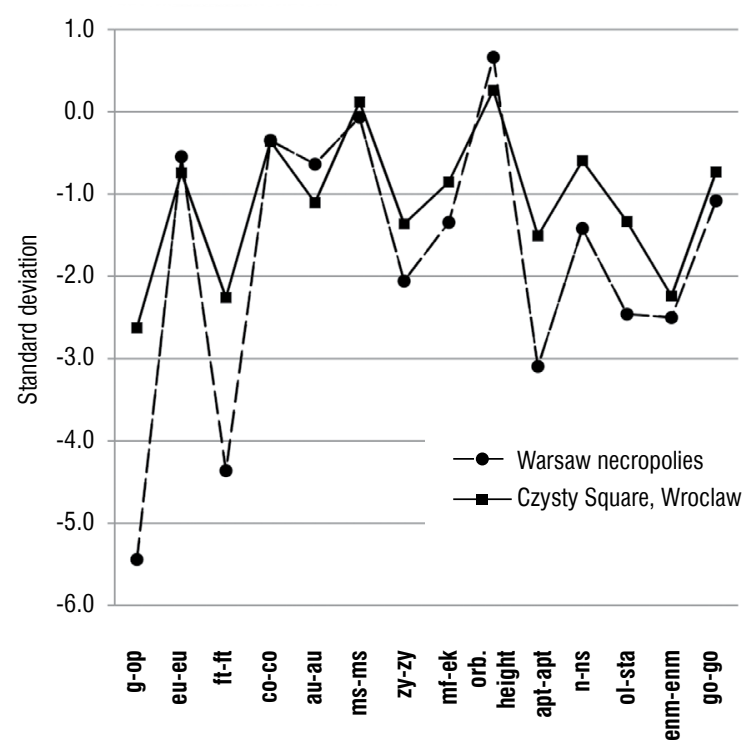

Figure 4. Chart of morphometric measurements. Profile presents normalised values of differences (in standard deviations) between measurements of the skull from grave No. 595 and mean values from the measurements for female skulls from Czysty Square in Wroclaw and Warsaw necropolises. Studied skull is smaller than average in every aspect, except of ms-ms and orbital height. Abbreviations see Table 1.

smaller than the average female skull from Wroclaw Salvator Cemetery and Warsaw cemeteries (Fig. 4). In this comparison, skull No. 595 may be considered very short in the g-op axis, quite narrow both in the neurocranial (ft-ft), facial (zy-zy, apt-apt) and palatal 
Table 2. Morphometric indices of skull No. 595

\begin{tabular}{lc}
\hline Morphometric index & Skull No. 595 \\
\hline go-go/zy-zy (mandibular-face width index) & $75.00 \%$ \\
enm-enm/ol-sta (palatal index) & $86.32 \%$ \\
eu-eu/g-op (cranial index) & $90.97 \%$ \\
ba-b/g-op (cranial length-height index) & $76.77 \%$ \\
ba-b/eu-eu (cranial breadth-height) & $84.40 \%$ \\
ba-b/(lg-op+eu-eu)*2) $\rightarrow$ (Hrdlička-Kóčka index) & $80.41 \%$ \\
ft-ft/eu-eu (frontal-parietal index) & $60.99 \%$ \\
ft-tt/zy-zy (fronto-jugal index) & $71.67 \%$ \\
apt-apt/n-ns (nasal index) & $45.65 \%$ \\
mf-ek/zy-zy (orbital-facial index) & $30.00 \%$ \\
Orb.heigh/mf-ek (orbital index) & $94.44 \%$ \\
\hline
\end{tabular}

(enm-enm) measurements. There was a significant reduction in the length of the alveolar arches (short ol-sta measurement), probably associated with the significantly reduced parameters of the neurocranium and splanchnocranium.

Morphometric indices calculated for both neurocranium and viscerocranium (Table 2) allowed defining the skull as short. Index eu-eu/g-op (91\%) defines the skull as ultrabrachycephalus, Hrdlička-Kočka index [ba-b/0.5*(g-op+eu-eu)] as metriocephalus (80.4\%), the fronto-jugal index ft-ft/zy-zy (71.7\%) - as very narrow, cranial breadth-height ba-b/eu-eu (84.4\%) as tapeinocranius, palatal index enm-enm/ol-sta (86.3\%) as brachostaphylinus and mandibular-face width index go-go/zy-zy (75\%) as medium $[20,21]$.

\section{Dental analysis}

The orthodontic assessment of the skull revealed a severe antemortem loss of dentition in the mandible and maxilla. In the maxilla, the only visible, symmetrically preserved teeth were the second molars, with a slight attrition on the occlusal surface.

On the Smith and Knight tooth wear scale, the score is 1 for right upper molar and 2 for left upper molar [19]. According to Brothwell scale, the studied individual was about 25-35 years old at the time of death [4]; however, this estimation may be misleading, as the premature loss of dentition could result in reduced wear of remaining teeth.

The most probable cause of the premature and almost complete loss of the permanent teeth was periodontitis, as the calculus deposit on remaining teeth covers large surface, what may be connected to the gingival recession caused by this disease [3].
In edentulous individuals pressure is distributed in a non-physiological manner, promoting further resorption of the lamina dura of alveolar arches [33].

Moreover, in the preserved maxillary second molars alveolar bone atrophy was identified symmetrically on both sides of the alveolar arch. Only one-third of the root was embedded in the alveolus. During routine macroscopic analysis of the surface of the alveolar arches in skull No. 595 we also detected impacted teeth: the upper and lower left third molars.

In the left maxillary alveolar arch molar eruption through the posterior surface of the maxillary tuberosity was found on the left side from the lateral lamina pterygoid process (Figs. 2C; 3). Its angulation is $60^{\circ}$ (which is defined as distoangular in Winter's classification [35]. The crown of impacted molar was above the apical third of second molar root and approximate to the maxillary sinus wall and therefore this tooth can be described using modified Archer's classification as class D [17].

In the mandible, the third retained impacted molar was detected after the left ramus was accidentally broken. This revealed an abnormally positioned permanent molar, with the crown oriented down towards the mandibular corpus (Figs. 2D-F; 3). Tooth crown is fully covered by the anterior border of the ramus. Its roots are fused into a single conical root, resulting in an enlarged pulp cavity. Due to the lack of neighbouring tooth, it is difficult to determine its precise angulation. However, it can be classified as "other" in Winter's classification (angulation over $100^{\circ}$ ). The positioning of mentioned molar and the density image of the bone structure around them corresponds with level $C$ (the highest position of the impacted tooth is found below the cervical line of the adjacent molar), class III (tooth completely embedded in ramus) in the Pell and Gregory's system [9].

\section{DISCUSSION}

Cases like this are rarely reported in paleopathological studies. Usually, retained tooth crowns face towards the top of the alveolar arch of the maxilla or mandible, following the direction of growth. In most cases (in modern studies), an impacted tooth is set in the vertical position in respect to second molar (about $38 \%$ of all impacted teeth, Fig. 1). Some researchers have suggested that the fracture of the mandibular ramus is considerably more frequent in individuals with impacted third molars, since they weaken the 
bone at the site, contributing to a thinning and weakening of the cancellous bone structure [14, 30, 31].

The lower third molars are usually impacted due to lack of space in the dental arch, misalignment or improper regulation of osteoclastogenesis and osteogenesis [27, 34]. Morphometric measurement allows classifying the examined skull as short, which could be the factor influencing the failed eruption of two teeth, however other factors (genetic or environmental) could not be excluded in our study.

Computer tomography imaging revealed that in skull No. 595 the third molar is located directly above the mandibular canal, at a very short distance from its upper wall. The position of the tooth could result in neuropathic pain, paraesthesias in the left gonial angle, or generalised headaches, due to compression of the inferior alveolar nerve [18]. Similar possible symptoms were described in our previous reports [7].

The discussed impacted maxillary third molar is also abnormally positioned, with the crown oriented towards the pterygopalatine fossa, and the root apex towards the deeper layers of the cortical bone in the left corpus of the maxillary bone.

Such teeth impaction could have resulted in deterioration of the quality of life of the studied individual. Upper impaction may cause pain, swelling, inflammation of the lower head of lateral pterygoid muscle and damage of lingual nerve. Lower impaction could damage the inferior alveolar nerve, ulceration at check/tongue and bone loss leading to weakening it structure [29]. There is no unequivocal explanation for the primary cause of periodontitis found in this individual. There is no abnormal porosity on the greater wings of the sphenoid bone, which is typical for vitamin C deficiency [3]. X-ray imaging did not reveal any rarefactions typical for osteoporosis, moreover - the individual was relatively young (most probably less than 35 years old), whilst osteoporosis occurs mostly in elderly individuals [13]. Other possible causes, such as bacterial disease, alcohol overuse or diabetes [24] could not be excluded nor unequivocally confirmed.

\section{CONCLUSIONS}

In conclusion, it should be pointed out that the atypical impaction of the third molars in skull No. 595 could have significantly deteriorated the quality of life in the studied individual. The correct identification of malformations within the masticator system and attempts to estimate the effects of pathological tooth eruption in the craniological material from Czysty Square in Wroclaw, possible with the use of modern research methods, can be a valuable contribution to studies on the reconstruction of the health status of historical populations living in Wroclaw, and also complements observations and clinical studies in contemporary orthodontics.

\section{Acknowledgements}

The authors would like to thank the Head of Department of Anthropology Polish Academy of Science Professor Stawomir Kozieł for allowing perform test on osteological material from Czysty Square in Wroclaw.

\section{REFERENCES}

1. Ayranci F, Omezli M, Sivrikaya E, et al. Prevalence of Impacted Wisdom Teeth in Middle Black Sea Population. J Clin Exp Investig. 2017; 8(2): 58-61, doi: 10.5799/jcei.333381.

2. Bilge NH, Yeşiltepe $\mathrm{S}$, Törenek Ağırman $\mathrm{K}$, et al. Investigation of prevalence of dental anomalies by using digital panoramic radiographs. Folia Morphol. 2018; 77(2): 323-328, doi: 10.5603/FM.a2017.0087, indexed in Pubmed: 28933802.

3. Brickley M, Ives R. The bioarchaeology of metabolic bone disease. 2008: 351.

4. Brothwell DR. Digging up bones: the excavation, treatment, and study of human skeletal remains. 3rd ed. British Museum, London 1981.

5. Buikstra J, Ubelaker D. Standards for data collection from human skeletal remains [Internet]. Vol. 44, Fayetteville Arkansas Archaeological Survey. 1994. http://core.tdar. org/document/323332 (cited 2016 Dec 15).

6. Chu FCS, Li TKL, Lui VKB, et al. Prevalence of impacted teeth and associated pathologies - a radiographic study of the Hong Kong Chinese population. 2003: 158-63.

7. Dąbrowski P, Gronkiewicz S, Soliński $D$, et al. A case of elongated styloid process in a modern-age skull from Puerto Cabello, Venezuela. Folia Morphol. 2015; 74(4): 475-478, doi: 10.5603/FM.2015.0110, indexed in Pubmed: 26620508.

8. Guszpit P, Mruczek R, Wojcieszak J, Wojcieszak M, Wójcik M. Pierwszy wrocławski cmentarz protestancki przy kościele imienia Salwatora - wstępne wyniki badań. In: Czechowicz B, editor. Śródmiejska Katedra Kościół św. Marii Magdaleny w dziejach i kulturze Wrocławia 2010.

9. Hatem M, Bugaighis I, Taher E. Pattern of third molar impaction in Libyan population: A retrospective radiographic study. Saudi J Dental Res. 2016; 7(1): 7-12, doi: 10.1016/j. sjdr.2015.04.005.

10. Javali R, Meti M. Prevalence of developmental anomalies of teeth in a group of North Karnataka population, India. Int J Dental Res. 2015; 3(1): 5, doi: 10.14419/ijdr.v3i1.4363.

11. Juodzbalys G, Daugela P. Mandibular third molar impaction: review of literature and a proposal of a classification. J Oral Maxillofac Res. 2013; 4(2): e1, doi: 10.5037/ jomr.2013.4201, indexed in Pubmed: 24422029.

12. Kim TW, Artun J, Behbehani F, et al. Prevalence of third molar impaction in orthodontic patients treated nonextraction and with extraction of 4 premolars. Am J Orthod 
Dentofacial Orthop. 2003; 123(2): 138-145, doi: 10.1067/ mod.2003.13, indexed in Pubmed: 12594419.

13. Kling JM, Clarke BL, Sandhu NP. Osteoporosis prevention, screening, and treatment: a review. J Womens Health (Larchmt). 2014; 23(7): 563-572, doi: 10.1089/ jwh.2013.4611, indexed in Pubmed: 24766381.

14. Krimmel M, Reinert $S$. Mandibular fracture after third molar removal. J Oral Maxillofac Surg. 2000; 58(10): 1110-1112, doi: 10.1053/joms.2000.9566, indexed in Pubmed: 11021704

15. Krzyżaniak M, Miszkiewicz B. Crania Polonica: Cmentarzyska Warszawskie z XVII-XIX w. [Warsaw Cemeteries from the XVIIth to the XIXth century]. Mater i Pr Antropol. 1955: 10

16. Leandro I, Rodrigues C, Gómez-Martínez S, et al. Ectopic eruption of a lower permanent molar from the mediaeval necropolis of Alcáçova do Castelo, Mértola, Portugal. Int J Paleopathol. 2017; 16: 1-4, doi: 10.1016/j. ijpp.2016.11.002, indexed in Pubmed: 28290304.

17. Lim AA, Wong CW, Allen JC. Maxillary third molar: patterns of impaction and their relation to oroantral perforation. J Oral Maxillofac Surg. 2012; 70(5): 1035-1039, doi: 10.1016/j.joms.2012.01.032, indexed in Pubmed: 22494509.

18. Loescher AR, Smith KG, Robinson PP. Nerve damage and third molar removal. Dent Update. 2003; 30(7): 375-380, 382, doi: 10.12968/denu.2003.30.7.375, indexed in Pubmed: 14558203.

19. López-Frías FJ, Castellanos-Cosano L, Martín-González J, et al. Clinical measurement of tooth wear: Tooth wear indices. J Clin Exp Dent. 2012; 4(1): e48-e53, doi: 10.4317/ jced.50592, indexed in Pubmed: 24558525.

20. Malinowski A, Bożiłow W. Podstawy Antropometrii. Metody, techniki, normy. PWN, Warszawa-tódź 1997.

21. Martin R, Saller K. Lehrbuch der Anthropologie. Stuttgart 1957.

22. Muhamad AH, Nezar W. Prevalence of Impacted Mandibular Third Molars in Population of Arab Israeli: A Retrospective Study. IOSR J Dent Med Sc. 2016; 15(1): 2279-2861.

23. Padhye MN, Dabir AV, Girotra CS, et al. Pattern of mandibular third molar impaction in the Indian population: a retrospective clinico-radiographic survey. Oral Surg Oral Med Oral Pathol Oral Radiol. 2013; 116(3): e161-e166, doi: 10.1016/j.000o.2011.12.019, indexed in Pubmed: 22819456.
24. Pihlstrom B, Michalowicz B, Johnson N. Periodontal diseases. Lancet. 2005; 366(9499): 1809-1820, doi: 10.1016/ s0140-6736(05)67728-8.

25. Pillai AK, Thomas S, Paul G, et al. Incidence of impacted third molars: A radiographic study in People's Hospital, Bhopal, India. J Oral Biol Craniofac Res. 2014; 4(2): 76-81, doi: 10.1016/j.jobcr.2014.04.001, indexed in Pubmed: 25737922.

26. Quek SL, Tay CK, Tay KH, et al. Pattern of third molar impaction in a Singapore Chinese population: a retrospective radiographic survey. Int J Oral Maxillof Surg. 2003; 32(5): 548-552, doi: 10.1016/s0901-5027(03)90413-9.

27. Sękowska A, Chałas R, Dunin-Wilczyńska I. Width of dental arches in patients with maxillary midline diastema. Folia Morphol. 2018; 77(2): 340-344, doi: 10.5603/ FM.a2017.0099, indexed in Pubmed: 29064544.

28. Şener S. Presence, Distribution, and Association of Dental Anomalies: a Clinical and Radiographical Study. Clin Dent Res. 2011; 35(3): 43-52.

29. Stanley J. Nelson. Wheeler's dental anatomy, physiology, and occlusion. 3rd ed. Elsevier, St Louis 2015.

30. Thangavelu A, Yoganandha R, Vaidhyanathan A. Impact of impacted mandibular third molars in mandibular angle and condylar fractures. Int J Oral Maxillofac Surg. 2010; 39(2): 136-139, doi: 10.1016/j.ijom.2009.12.005, indexed in Pubmed: 20083388.

31. Tomaszewska IM, Zwinczewska H, Gładysz T, et al. Anatomy and clinical significance of the maxillary nerve: a literature review. Folia Morphol. 2015; 74(2): 150-156, doi: 10.5603/FM.2015.0025, indexed in Pubmed: 26050800.

32. Wachowski K, Klápště J, Krabath $S$, et al. I. Wratislavia Antiqua, t. 21. Cmentarz Salwatora. Pierwsza nekropolia wrocławskich protestantów. Uniwersytet Wrocławski, Instytut Archeologii. 2015.

33. White TD, Black M, Folkens P. Human osteology. Berkeley, California 2012.

34. Wise GE. Cellular and molecular basis of tooth eruption. Orthod Craniofac Res. 2009; 12(2): 67-73, doi: 10.1111/j.16016343.2009.01439.x, indexed in Pubmed: 19419449.

35. Yilmaz S, Adisen MZ, Misirlioglu M, et al. Assessment of third molar impaction pattern and associated clinical symptoms in a central anatolian Turkish population. Med Princ Pract. 2016; 25(2): 169-175, doi: 10.1159/000442416, indexed in Pubmed: 26566129. 